\title{
Serological study of feline leishmaniasis and molecular detection of Leishmania infantum and Leishmania braziliensis in cats (Felis catus)
}

\author{
Pesquisa sorológica da leishmaniose felina e detecção molecular de \\ Leishmania infantum e Leishmania braziliensis em gatos (Felis catus)
}

\begin{abstract}
Adriane Pimenta da Costa-Val1* (1); Fernanda Morcatti Coura²; Jonata de Melo Barbieri³; Luiza Diniz; Agnes Sampaio4; Jenner Karlisson Pimenta dos Reis³; Bruna Lopes Bueno33; Célia Maria Ferreira Gontijo ${ }^{4}$

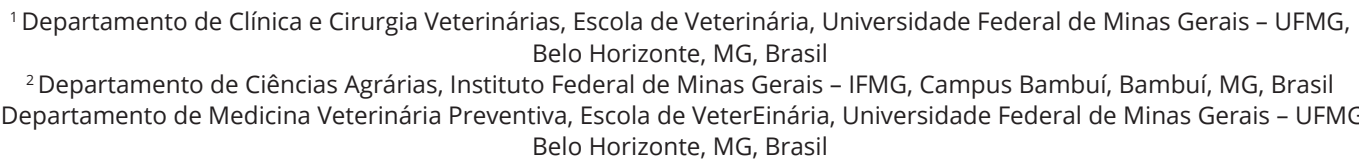

How to cite: Costa-Val AP, Coura FM, Barbieri JM, Diniz L, Sampaio A, Reis JKP, et al. Serological study of feline leishmaniasis and molecular detection of Leishmania infantum and Leishmania braziliensis in cats (Felis catus). Braz J Vet Parasitol 2020; 29(2): e003520. https://doi.org/10.1590/S1984-29612020023

\begin{abstract}
Blood samples and swabs from ocular conjunctiva and mouth were obtained from 64 cats. Of 64 serum samples, 19 were positive for Leishmania antibodies by ELISA (29.80\%). Eight cats were positive by PCR (12.5\%) in swab samples from mouth and/or ocular mucosa. Poor kappa agreement between serological and molecular results $(k=0.16)$ was obtained. From five positive PCR samples one was L. braziliensis and four were L. infantum. Phylogenetic analysis performed with the five isolates of Leishmania, showed that samples of L. infantum isolated from the cats were phylogenetically close to those isolated from domestic dogs in Brazil, while the L. braziliensis is very similar to the one described in humans in Venezuela. The study demonstrated that, despite high seropositivity for Leishmania in cats living in the study region, poor agreement between serological and molecular results indicate that positive serology is not indicative of Leishmania infection in cats. Parasite DNA can be detected in ocular conjunctiva and oral swabs from cats, indicating that such samples could be used for diagnosis. Results of phylogenetic analyzes show that $L$. infantum circulating in Brazil is capable of infecting different hosts, demonstrating the parasite's ability to overcome the interspecies barrier.
\end{abstract}

Keywords: ELISA, Leishmania infantum, Leishmania braziliensis, oral and conjunctival swabs, PCR swab.

\section{Resumo}

Amostras de sangue e swabs da conjuntiva ocular e oral foram obtidas de 64 gatos. Das 64 amostras de soro, 19 foram positivas para anticorpos contra Leishmania por ELISA (29,80\%). Oito gatos foram positivos por PCR (12,5\%) em amostras de swab da boca e / ou mucosa ocular. Demonstrou-se baixa concordância kappa entre os resultados sorológicos e moleculares $(\mathrm{k}=0,16)$. Das cinco amostras positivas para PCR, uma era $L$. braziliensis e quatro eram $L$ infantum. A análise filogenética realizada com os cinco isolados de Leishmania, mostrou que amostras de $L$. infantum, isoladas dos gatos, eram filogeneticamente próximas às isoladas de cães domésticos do Brasil enquanto L. braziliensis era muito semelhante ao descrito em humanos na Venezuela. O estudo demonstrou que, apesar da alta soropositividade para Leishmania, em gatos que vivem na região do estudo, pouca concordância entre os resultados sorológicos e moleculares indica que a sorologia positiva não é indicativa de infecção por Leishmania em gatos. O DNA do parasita pode ser detectado na conjuntiva ocular e nas zaragatoas orais de gatos, indicando que essas amostras podem ser usadas para o diagnóstico. Resultados de análises filogenéticas mostram que L. infantum, circulando no Brasil, é capaz de infectar diferentes hospedeiros, demonstrando a capacidade do parasita de superar a barreira interespécies.

Palavras-chave: ELISA, Leishmania infantum, Leishmania braziliensis, swabs oral e conjuntival, PCR de swab. 


\section{Introduction}

Visceral Leishmaniasis (VL) is a zoonosis caused by Leishmania infantum (Baneth et al., 2008). Dogs are considered the main reservoir of the parasite in domestic and peridomestic areas; however, recent studies have reported cats infected with the protozoan and capable of acting as infectious reservoirs (Maroli et al., 2007; Maia \& Campino 2011).

Leishmania infantum is transmitted by the bite of phlebotomine sandflies, primarily by Lutzomyia longipalpis and secondarily by Lutzomyia cruzi in Brazil (Andrade-Filho et al., 2017). The most frequent clinical signs of leishmaniasis in cats include skin changes, such as papules, nodules, ulcers, and alopecia (Silveira et al., 2015); ocular signs have also been described (Pimenta et al. 2016). Leishmania species identified in cats include L. mexicana, L. venezuelensis, L. braziliensis, L. amazonensis, and L. infantum (Pennisi et al., 2015). Leishmania infection shows different clinical presentations in the affected hosts as a result of the Leishmania species and the host immune response. L. braziliensis is associated with cutaneous and mucosal leishmaniasis and L. infantum with visceral and cutaneous (unusual presentation) (Pace, 2014). Notably, it was demonstrated that cats showing dermatological lesions were highly associated with visceral leishmaniasis (Vides et al., 2011).

Studies have examined the seroprevalence of Leishmania (Baldini-Peruca et al., 2017; Benassi et al., 2017; Braga et al., 2014; Cardia et al., 2013; Coura et al., 2018; Noe et al., 2015; Oliveira et al., 2015a; Silva et al., 2014; Sobrinho et al., 2012) or the occurrence of natural cases of leishmaniasis (Passos et al., 1996; Savani et al., 2004; Schubach et al., 2004; Souza et al., 2005; Coelho et al., 2010; Silva et al., 2010) in cats in Brazil.

The use of noninvasive sampling techniques is of interest, especially in feline medicine (Athanasiou et al., 2018). Recently Leishmania DNA was detected from conjunctival (Benassi et al., 2017) and oral swabs of cats (Persichetti et al., 2018).

The Leishmania genus is a slowly evolving monophyletic group and includes important human pathogens (Marcili et al., 2014). Despite the widespread distribution of leishmaniasis among humans and animals in Brazil, little is known about the genetic characteristics of the causative agents. Moreover, phylogenetic studies have focused on human or canine strains (Cortes et al., 2014), while very few of them involve genetic analysis of Leishmania obtained from cats (Ceccarelli et al., 2018; Pereira et al., 2020).

Since cats are potential reservoirs of Leishmania and no study has identified the presence of Leishmania DNA in oral swabs from cats in Brazil, the objectives of the present study were to investigate the occurrence of Leishmania antibodies in cats from a region endemic for canine and human leishmaniasis by ELISA and the presence of Leishmania DNA using PCR analysis of ocular conjunctiva and oral swab samples. From the genomic sequences of the Leishmania isolates, a characterization and evaluation of the phylogenetic relationships between Leishmania strains based on the Leishmania Internal transcribed spacer 1 (ITS1) gene was made.

\section{Materials and Methods}

\section{Animals}

The study included 64 cats (Felis catus) living in Belo Horizonte and Confins in Minas Gerais State, Brazil. These municipalities are endemic for canine leishmaniasis ( $\mathrm{CanL}$ ) and have also registered human cases of leishmaniasis (Silva, 2015; Belo Horizonte, 2019). The collection of the biological samples was carried out with the permission of the owners and the experimental procedures were approved by the Ethics Committee on Animal Experimentation, UFMG (CETEA 242/2014). All procedures performed were in accordance with the ethical standards of the institution or practice at which the studies were conducted

Cats were clinically evaluated before sample collection and were clinically healthy upon examination. Cats of either sex and of any breed and age were included in this study.

\section{Sample collection}

Using disposable syringes and needles, $5 \mathrm{~mL}$ blood samples were collected from the jugular or cephalic veins of the cats and transferred into tubes without anticoagulant. Blood samples were centrifuged at $1500 \times g$ for $6 \mathrm{~min}$, and $1 \mathrm{~mL}$ of the separated serum was transferred into plastic microtubes and stored at $-20^{\circ} \mathrm{C}$ for serological analysis. 
Sterile swabs manufactured for use in bacteriological isolation were used for the collection of specimens for Leishmania DNA analysis. Swabs were rubbed on the lower portion of both ocular conjunctiva and on the right of the oral mucosal of the lips of each cat. The ends of the swabs were separated and stored in $1.5 \mathrm{~mL}$ microtubes at $-20^{\circ} \mathrm{C}$ until processing for PCR analyses. DNA extraction was performed using Gentra ${ }^{\circledR}$ Puregene ${ }^{\circledR}$ Tissue Kits (Qiagen), according to the manufacturer's instructions.

\section{Enzyme-linked immunosorbent assay (ELISA)}

Serum samples were tested for Leishmania antibodies by ELISA (Voller et al., 1979). Soluble Leishmania antigen was produced from promastigote forms of Leishmania (Leishmania) infantum strain MHOM/BR/1967/BH46. Previously known positive (optical density [OD]: 0.340) and negative (OD: 0.060) sera were used as controls. The cutoff point was calculated as the median of positive and negative sera, plus four times standard value (Solano-Gallego et al., 2007). Values above OD: 0.955 were considered positive. All samples were tested in duplicate.

\section{PCR assays}

\section{Leishmania kinetoplast DNA}

All ocular conjunctiva, and mouth mucosa cells were analyzed by PCR to detect Leishmania minicircle kinetoplast DNA (kDNA), generating a 120bp fragment as described by Degrave et al. (1994) and Passos et al. (1996). Briefly, PCR assays were performed in a total volume of $25 \mu \mathrm{L}$ containing $5 \mu \mathrm{L}$ DNA template, $0.2 \mathrm{mM}$ DNTPs, $1.5 \mathrm{mM}$ $\mathrm{MgCl}_{2}, 1.5 \mu \mathrm{L}$ DMSO 5\%, $0.4 \mu \mathrm{M}$ each primer, buffer (10 mM Tris-HCl, $50 \mathrm{mM} \mathrm{KCl} ; \mathrm{pH} 8.0$ ) and $1.25 \mathrm{U}$ of Taq DNA polymerase (Invitrogen ${ }^{\mathrm{TM}}$, Carlsbad, CA, USA). PCR conditions were as follows: initial denaturation at $94^{\circ} \mathrm{C}$ for $5 \mathrm{~min}$, followed by $35 \mathrm{cycles}$ at $94^{\circ} \mathrm{C}$ for $30 \mathrm{sec}, 61^{\circ} \mathrm{C}$ for $1 \mathrm{~min}$, and $72^{\circ} \mathrm{C}$ for $3 \mathrm{~min}$, with a final extension at $72^{\circ} \mathrm{C}$ for 10 min. Negative (no DNA) and positive (0.01 and 1.0 pg of Leishmania DNA) PCR controls were included in each set of reactions. Positive control for the PCR reactions included DNA extracted from promastigote forms of the L. infantum (MHOM/BR/74/PP75) strain.

\section{Leishmania internal transcribed spacer 1 (ITS1)}

Further analyses from PCR positive samples were performed to identify the Leishmania species. DNA extracted from cat samples was used as a template for detection of Leishmania via amplification of a 300-350 bp fragment of an intergenic region in the Leishmania genome (ITS1), using the primers LITSR: 5'-CTGGATCATTTTCCGATG-3' and L5.8S: 5'-TGATACCACTTATCGCACTT-3' (El Tai et al., 2000; Schönian et al., 2003). Positive controls for the PCR reactions included DNA extracted from promastigote forms of the following Leishmania strains: L. amazonensis (IFLA/BR/67/PH8), L. braziliensis (MHOM/BR/75/M2903), L. infantum (MHOM/BR/74/PP75), and L. guyanensis (MHOM/BR/75/M4147).

\section{Gel electrophoresis of PCR products}

Amplification products were subjected to electrophoresis in $2 \%$ agarose gels, with a 100 bp DNA Step Ladder as a molecular weight size standard and stained with ethidium bromide $(10 \mathrm{mg} / \mathrm{mL})$. To identify Leishmania species ITS1 PCR products were digested with HaellI $(10 \mathrm{U} / \mu \mathrm{L})$ using the conditions recommended by the supplier (Promega). Restriction digest profiles were analyzed by electrophoresis in 3\% agarose gels, stained with ethidium bromide $(10 \mathrm{mg} / \mathrm{mL})$, and compared with Leishmania reference strains.

\section{Sanger sequencing}

Amplicons from positive samples by ITS1-PCR were purified using QIAquick PCR Purification kit (QIAGEN, Germantown, MD, USA), following the manufacturer's instructions. Purified fragments were sequenced using a Big Dye Terminator v3.1 Cycle Sequencing Kit (Applied Biosystems, Foster City, CA, USA) in a final reaction volume of $8 \mu \mathrm{L}$ containing $10 \mathrm{ng}$ of purified PCR product and $5.0 \mathrm{pmol}$ of the forward and reverse primers. Sequences were generated using an ABI 3730xI DNA Analyzer, and the software Finch TV (Geospiza, Inc., USA) was used to analyze electropherograms and align sequences with others obtained from GenBank. 


\section{Phylogenetic analysis}

We retrieved from GenBank database fifty-nine published sequence of internal transcribed spacer 1 and 5.8S ribosomal gene of Leishmania infantum and eighteen complete sequence of Leishmania braziliensis, sampled of cats, dogs and human in worldwide. The L. infantum sequences were collected from the Middle east (Turkey, Iran, Israel, Tunisia), Southeast Europe (Italy, Spain, Romania and Greece) and South America (Argentina and Brazil) while the L. braziliensis sequences were collected from the South America (Brazil and Venezuela) and North America (United States of America).

The sequences were aligned for ClustalW method using the BioEdit v7.0.5 software (Sanchez-Villeda et al., 2008). A maximum likelihood (ML) phylogenetic analysis was performed through the IQ-TREE software (Nguyen et al., 2015). Prior the analysis, the jModelTest 2.1.7 software (Darriba et al., 2012), was used to select the best-fitted nucleotide substitution model for the dataset. The ML estimate tree was subsequently visualized in FigTree v1.4.4 (http://tree.bio.ed.ac.uk/software/figtree/). Support was evaluated using the Shimodaira-Hasegawa approximate likelihood ratio test (SH-aLRT) (Guindon et al., 2010) and the ultrafast bootstrap approximation (UFBoot) (Minh et al., 2013) with 1000 replicates each.

\section{Statistical analysis}

The kappa agreement between the results of PCR from oral and ocular conjunctiva swabs was determined using Cohen's kappa test. The results are expressed as follows: no agreement $(k<0)$, poor agreement $(0<k<0.2)$, fair agreement $(0.2<\mathrm{k}<0.4)$, moderate agreement $(0.4<\mathrm{k}<0.6)$, substantial agreement $(0.6<\mathrm{k}<0.8)$, and almost perfect agreement ( $\mathrm{k}>0.8$ ) (Altman, 1999). Analyses were conducted using R (R version 3.1.1, R Development Core Team, New Zealand).

\section{Results}

Of 64 feline serum samples collected, 19 were positive for Leishmania antibodies based on ELISA results, representing $29.80 \%$ seropositivity.

PCR analysis revealed that oral swabs from four animals (6.25\%) were positive for Leishmania, only one of which was also positive by ELISA. PCR analysis of the ocular conjunctiva revealed that two cats were positive in the right eye, two in the left eye, and one animal positive in both eyes, totaling five positive cats (7.81\%), one of which was also positive by PCR from an oral swab sample. In total, eight cats were positive by PCR (12.5\%). There was poor agreement between the serological and molecular test results $(k=0.16)$. Results are summarized in Table 1.

Table 1. Results of the diagnostic tests for Leishmania applied to 64 cats from Belo Horizonte and Confins, Minas Gerais, Brazil.

\begin{tabular}{|c|c|c|c|c|}
\hline \multicolumn{4}{|c|}{ Diagnostic Testing Technique } & \multirow{2}{*}{$\mathrm{N}^{\circ}$ of observations } \\
\hline ELISA & OM PCR & LOM swab PCR & ROM swab PCR & \\
\hline- & - & - & - & 41 \\
\hline- & - & + & - & 1 \\
\hline- & + & - & - & 2 \\
\hline+ & - & - & - & 16 \\
\hline- & - & + & + & 1 \\
\hline+ & - & - & + & 2 \\
\hline- & + & + & - & 1 \\
\hline+ & + & - & - & 1 \\
\hline
\end{tabular}

Abbreviations: OM: oral mucosa; LOM: left ocular mucosa, ROM: right ocular mucosa, PCR polimerase chain reaction.

PCR RFLP ITS1 detected Leishmania DNA in five of eight kDNA positive samples. It was not possible to perform PCR analysis on DNA of three cats. At the species level, four samples were identified as positive for $L$. infantum and one for $L$. braziliensis, the latter detected in an oral swab. The five positive samples were subjected to sequencing 
analysis, which confirmed four as L. infantum and one as L. braziliensis. L. infantum was found in both oral and ocular conjunctival swabs. Results and GenBank accession numbers for the nucleotide sequences are summarized in Table 2.

Table 2. Results of Leishmania species isolation of 5 cats from Belo Horizonte and Confins, Minas Gerais, Brazil.

\begin{tabular}{cccc}
\hline Cat & Source of biological material & Species isolated & GenBank accession number \\
\hline C6 & OM & L. infantum & MN245031 \\
C7 & OM & L. infantum & MN245032 \\
C10 & LOM/ROM & L. infantum & MN245033 \\
C21 & OM & L. braziliensis & MN245034 \\
C46 & OM & L. infantum & MN245035 \\
\hline
\end{tabular}

Abbreviations: OM: oral mucosa; LOM: left ocular mucosa, ROM: right ocular mucosa.

Phylogenetic analysis (Figure 1) showed that Leishmania spp. found in this study form two monophyletic groups. The first group is composed of $L$. infantum isolates, and the subdivision of isolates has no relation to origin or with the species in which the parasite was found. However, in the first group, composed basically of $L$. infantum, a clade of $L$. braziliensis isolates from Brazilian dogs and a human from the USA was formed.

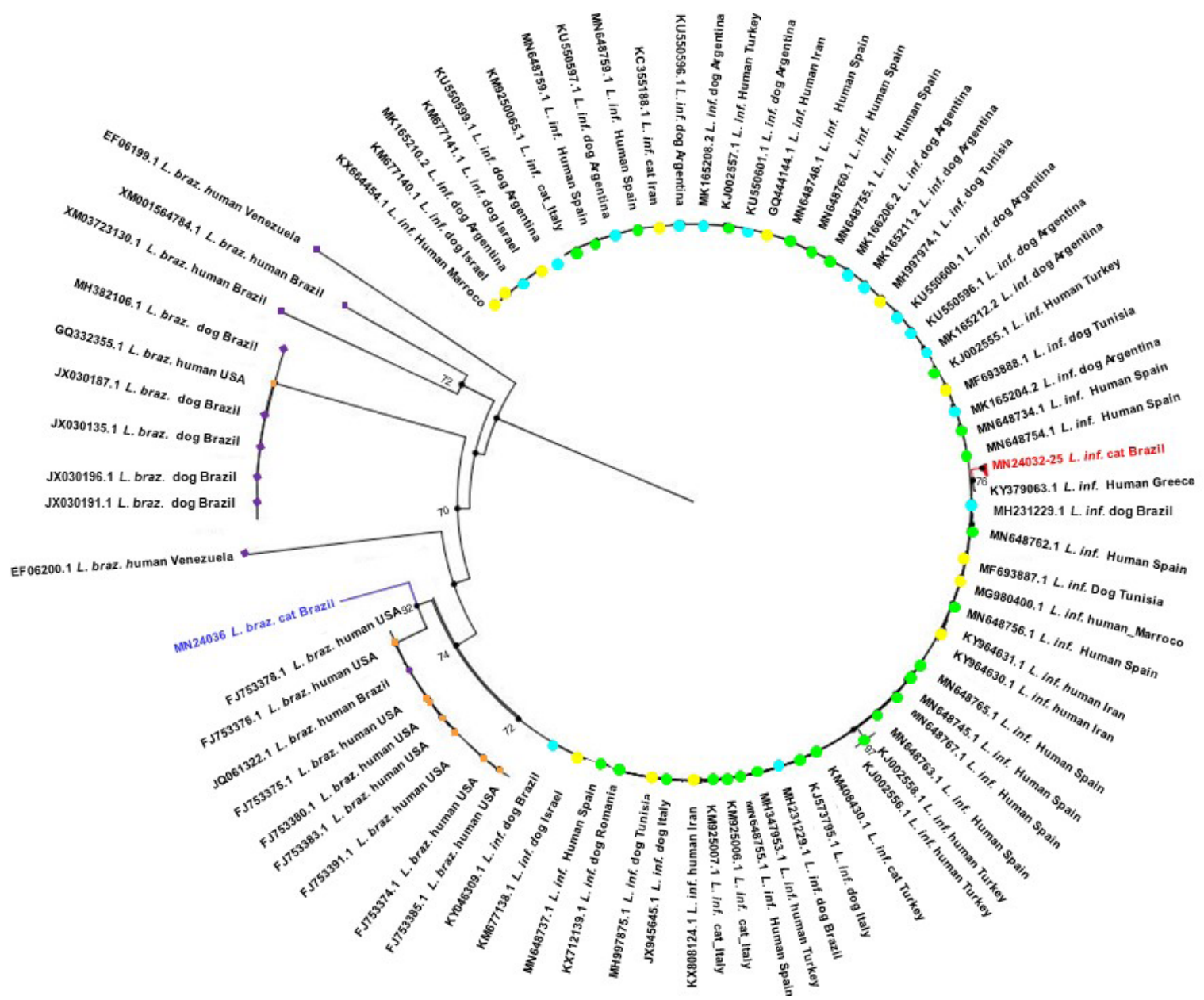

Figure 1. The Phylogeny of Leishmania species according to the maximum-likelihood (ML), tree was conducted based on the multiple sequence alignment of ITS-rDNA by IQTREE 1.6.1. Only bootstrap values of higher than $80 \%$ are indicated on each branch. Distance represents the number of base substitutions per site. The tree was constructed by using the Kimura 2-parameter model. Besides the haplotypes reported in this study, a number of accession numbers from other countries were applied in phylogenetic analysis. 
In addition, the second group was formed exclusively by L. braziliensis isolates from humans from Brazil, Venezuela and the USA.

Although, the $L$. infantum isolates from cats detected in this study form a single cluster, similar to the human isolate from Greece and the isolates found in dogs in Brazil, they are phylogenetically distant from the L. infantum strains found in domestic cats from other countries as Italy, Turkey and Iran (Supplementary Material Figure S1 A). However, the L. braziliensis isolate found in a Brazilian domestic cat is very similar to the strains circulating in Venezuela (Supplementary Material Figure S1 B).

\section{Discussion}

Studies in Brazil and other countries have investigated the occurrence of feline leishmaniasis; however, many questions remain to be answered (Maia \& Campino, 2011; Pennisi \& Persichetti, 2018). The present study was conducted in Belo Horizonte and Confins, Minas Gerais, which are both regions where cases of leishmaniasis have been registered in humans and dogs. Although dogs are the main hosts and reservoir for Leishmania infantum (Maia \& Campino, 2011), our study demonstrated the presence of DNA from this parasite in conjunctiva swabs from cats and, for the first time in Brazil, in oral mucosa swabs, calling attention to the presence of parasite DNA in these sites and suggesting that these tissues could be sampled for diagnosis. Moreover, sequence analysis identified L. braziliensis in one oral swab and L. infantum in an eye conjunctiva sample.

Leishmania infection results in different clinical manifestations depending on the immune response of the host and the protozoan species detected, being L. infantum associated with visceral and cutaneous Leishmaniasis (unusual) and L. braziliensis with cutaneous manifestation of the disease (tegumentary leishmaniasis) (Loeuillet et al., 2016; Pace, 2014). Cats with dermatological lesions might present visceral leishmaniasis (Vides et al., 2011) and both cited species have been identified in cats (Pennisi \& Persichetti, 2018). Positive cats subjected to xenodiagnosis assays can infect the Leishmania vector (Maroli et al., 2007) and Leishmania braziliensis can be detected in skin samples from experimentally chronically infected cats (Simões-Mattos et al., 2005). Recently, in the same region of the present study, L. braziliensis DNA was detected in conjunctival swab of dogs (Souza et al., 2019), highlighting the importance of detecting Leishmania species not only in dogs but also in cats, to better understand the role of these hosts in the epidemiology of tegumentary leishmaniasis.

In our study, $40.63 \%$ of evaluated cats were seropositive for antibodies against Leishmania by ELISA. The frequency of feline seropositivity varies between regions, and caution is advised when comparing this result with those of other studies, since variables, such as serological technique, the level of endemicity, and cross-reaction with other Leishmania species or parasites, can interfere with the results. The seropositivity rate for Leishmania antibodies has been reported as 16.1\% in Spain (Martín-Sánchez et al., 2007), 0\% in Angola (Lopes et al., 2017), 6.7\% in Jerusalem (Nasereddin et al., 2008), 24.27\% in Iran (Mohebali et al., 2017), 3.87\% to 21.6\% in Greece (Diakou et al., 2009; Chatzis et al., 2014), and 25.3\% in Italy (Spada et al., 2013). In Brazil, the reported frequency of seropositivity for feline Leishmania antibodies determined by ELISA varies from 3.9\% in Pernambuco (Silva et al., 2014) to 11.50\% and 15.23\% in São Paulo (Costa et al., 2010; Sobrinho et al., 2012). The discrepancies are due to different levels of endemicity, type of feline populations included in the study and, mainly, different methodologies, especially validation of the serological test (Pennisi, 2015). A previous study conducted in Minas Gerais, showed that $54 \%$ of the cats were seropositive for Leishmania antibodies by immunofluorescence antibody test (Coura et al., 2018). The high frequency of feline Leishmania seropositivity observed in the present study can be explained by possible occurrence of co-infections with other pathogens (Sobrinho et al., 2012), or the assay performed may have exhibited cross-reaction with antibodies against other parasites (Andrade et al., 2009; Luciano et al., 2009; Soares et al., 2016), although cats do not mount a humoral response like dogs (Solano-Gallego et al., 2007).

Studies of feline leishmaniasis using PCR have used DNA from blood (Martín-Sánchez et al., 2007; Maia et al., 2010; Sherry et al., 2011; Spada et al., 2013; Akhtardanesh et al., 2017), ocular conjunctiva (Chatzis et al., 2014; Oliveira et al., 2015b), urine (Persichetti et al., 2018) and lymphoid organs (Coelho et al., 2011; Noe et al., 2015; Mohebali et al., 2017; Otranto et al., 2017); however, this is the first report of Leishmania DNA identification in oral mucosa swabs from cats in Brazil, supporting recently found results (Persichetti et al., 2018). This finding is important, since there is no consensus on the ideal biological sample for use in cytological or molecular diagnosis of feline leishmaniasis (Braga et al., 2014; Chatzis et al., 2014; Noe et al., 2015; Akhtardanesh et al., 2017). Low production of antibodies by cats (Solano-Gallego et al., 2007) and cross-reactions with other microorganisms that may occur highlights the need for different diagnostic tools for feline leishmaniasis (Noe et al., 2015). Furthermore, we performed sequencing 
analysis of five DNA samples, which confirmed the presence of L. infantum and L. braziliensis DNA in swab samples evaluated, indicating that infections with these two species might occur in the region of the study.

Phylogenetic analyzes for L. infantum showed low divergence between parasite isolates in cats from Minas Gerais, Brazil. However, there was no direct correlation between the isolates of this study and the other L.infantum isolates from domestic cats described in countries such as Italy, Iran or Turkey (Can et al., 2016; Spada et al., 2016; Mohebali et al., 2017). These results show the genetic complexity of Leishmania spp. populations which circulate in a different geographical area but in the same species (Cupolillo et al., 1998; Ortuño et al., 2019). On the other hand, isolated samples from Brazilian domestic cats were phylogenetically close to isolated samples from domestic dogs, which indicates that possibly L. infantum circulating in Brazil is present in both species. Mohammadiha et al.(2013) identified similar results for dogs and humans, demonstrating the parasite's ability to overcome the interspecies barrier.

Regarding L. braziliensis, the feline sample found in the country is very similar to the isolate described in Venezuela. Aguilar et al. (1989) have already observed that the L. braziliensis strain responsible for an outbreak of cutaneous leishmaniasis that affected humans, dogs and horses in Venezuela was the same strain that circulated in Brazil. The circulation of L. braziliensis between the countries occurs through the presence of the hematophagous vectors Lutzomyia panamensis in Venezuela and Lutzomyia intermedia in Brazil, which perform the blood support in horses and eventually dogs. These hosts transit between Brazil and Venezuela border and have peridomestic habits, allowing the maintenance of the parasite in the environment. Because of this, the strains of Leishmania spp. circulating between the hosts of the two countries have high genetic similarity.

Our study found poor agreement between the results generated using ocular conjunctiva and those from oral mucosa swabs. Other studies have reported inconsistent results when using different types of tissue samples for PCR-based diagnosis compared with parasitological and serological data (Akhtardanesh et al., 2017; Baldini-Peruca et al., 2017; Braga et al., 2014; Chatzis et al., 2014; Diakou et al., 2009; Maia et al., 2010; Noe et al., 2015; Oliveira et al., 2015b; Sherry et al., 2011), indicating that sampling from different tissues together with serological analysis is required when screening for feline leishmaniasis. The study was conducted with 64 cats and use ELISA for serological tests, and these factors should be considered as limitations for further conclusions of cat role in the epidemiology of leishmaniases.

\section{Conclusion}

Our findings revealed a high seroprevalence for leishmaniasis in cats and parasite DNA was detected in feline oral and conjunctival swabs. Moreover, sequence analysis detected L. infantum and L. braziliensis in these sites. These results highlight that oral mucosa swabs can also be used for diagnosis, alongside another diagnostic tool. Poor agreement between serological and molecular results indicates that positive serology cannot be used as indicative of Leishmania infection in cats. The results of phylogenetic analyzes show that $L$. infantum circulating in Brazil is capable of infecting different hosts, demonstrating the parasite's ability to overcome the interspecies barrier. In addition, the L. braziliensis transits between hosts with peridomestic habitats, present on the Brazil and Venezuela border, allowing the maintenance of the parasite in the environment. There is a need to continue the standardization of diagnostic procedures for feline leishmaniasis and for further investigation of the role of cats as reservoirs of Leishmania.

\section{Acknowledgments \\ CNPq, Fapemig, Capes, Fiocruz, UFMG}

\section{References}

Aguilar CM, Rangel EF, Garcia L, Fernandez E, Momen H, Grimaldi Filho G, et al. Zoonotic cutaneous leishmaniasis due to Leishmania (Viannia) braziliensis associated with domestic animals in Venezuela and Brazil. Mem Inst Oswaldo Cruz 1989; 84(1): 19-28. http:// dx.doi.org/10.1590/S0074-02761989000100005. PMid:2319948.

Akhtardanesh B, Sharifi I, Mohammadi A, Mostafavi M, Hakimmipour M, Pourafshar NG. Feline visceral leishmaniasis in Kerman, southeast of Iran: serological and molecular study.J Vector Borne Dis 2017; 54(1): 96-102. PMid:28352052.

Altman DG. Practical statistics for medical research. Chapman \& Hall: London; 1999. 
Andrade ARO, Nunes VLB, Galati EAB, Arruda CCP, Santos MFC, Rocca MEG, et al. Epidemiological study on leishmaniasis in an area of environmental tourism and ecotourism, State of Mato Grosso do Sul, 2006-2007. Rev Soc Bras Med Trop 2009; 42(5): 488-493. http://dx.doi.org/10.1590/S0037-86822009000500003. PMid:19967228.

Andrade-Filho JD, Scholte RGC, Amaral ALG, Shimabukuro PHF, Carvalho OS, Caldeira RL. Occurrence and Probability Maps of Lutzomyia longipalpis and Lutzomyia cruzi (Diptera: Psychodidae: Phlebotominae) in Brazil. J Med Entomo/ 2017; 54(5): 1430-1434. http://dx.doi.org/10.1093/jme/tjx094. PMid:28472338.

Athanasiou L, Psemmas D, Papaioannou N. Conjunctival cytology assessment in dogs and cats. Sampling, diagnostic techniques and findings. J Helenic Vet Med Soc 2018; 69(1): 701-710. http://dx.doi.org/10.12681/jhvms.16382.

Baldini-Peruca L, Lucheis SB, Tome RO, Richini- Pereira VB, Correa APFL, Troncarelli MZ, et al. Infecção por Leishmania infantum (syn. chagasi) em gatos provenientes de uma área endêmica para leishmaniose canina e humana, na região sudeste do Brasil. Vet Zootec 2017; 24(1): 216-225.

Baneth G, Koutinas AF, Solano-Gallego L, Bourdeau P, Ferrer L. Canine leishmaniosis - new concepts and insights on an expanding zoonosis: part one. Trends Parasitol 2008; 24(7): 324-330. http://dx.doi.org/10.1016/j.pt.2008.04.001. PMid:18514028.

Belo Horizonte. Prefeitura Municipal. Leishmaniose visceral humana [online]. Belo Horizonte: Prefeitura Municipal; 2019 [cited 2019 May 3]. Available from: https://prefeitura.pbh.gov.br/saude/informacoes/vigilancia/vigilancia-epidemiologica/doencastransmissiveis/leishmaniose

Benassi JC, Benvenga GU, Ferreira HL, Pereira VF, Keid LB, Soares R, et al. Detection of Leishmania infantum DNA in conjunctival swabs of cats by quantitative real-time PCR. Exp Parasitol 2017; 177: 93-97. http://dx.doi.org/10.1016/j.exppara.2017.04.004. PMid:28438522.

Braga ARC, Langoni H, Lucheis SB. Evaluation of canine and feline leishmaniasis by the association of blood culture, immunofluorescent antibody test and polymerase chain reaction. J Venom Anim Toxins Incl Trop Dis 2014; 20(1): 1-7. http://dx.doi. org/10.1186/1678-9199-20-5. PMid:24565284.

Can H, Döşkaya M, Özdemir HG, Şahar EA, Karakavuk M, Pektaş B, et al. Seroprevalence of Leishmania infection and molecular detection of Leishmania tropica and Leishmania infantum in stray cats of Izmir, Turkey. Exp Parasitol 2016; 167: 109-114. http:// dx.doi.org/10.1016/j.exppara.2016.05.011. PMid:27260567.

Cardia DFF, Camossi LG, Neto LS, Langoni H, Bresciani KDS. Prevalence of Toxoplasma gondii and Leishmania spp. infection in cats from Brazil. Vet Parasito/ 2013; 197(3-4): 634-637. http://dx.doi.org/10.1016/j.vetpar.2013.07.017. PMid:23932640.

Ceccarelli M, Diotallevi A, Andreoni F, Vitale F, Galluzzi L, Magnani M. Exploiting genetic polymorphisms in metabolic enzymes for rapid screening of Leishmania infantum genotypes. Parasit Vectors 2018; 11(1): 572. http://dx.doi.org/10.1186/s13071-0183143-7. PMid:30382928.

Chatzis MK, Andreadou M, Leontides L, Kasabalis D, Mylonakis M, Koutinas AF, et al. Cytological and molecular detection of Leishmania infantum in different tissues of clinically normal and sick cats. Vet Parasitol 2014; 202(3-4): 217-225. http://dx.doi. org/10.1016/j.vetpar.2014.02.044. PMid:24629427.

Coelho WMD, Lima VMF, Amarante AFT, Langoni H, Pereira VBR, Abdelnour A, et al. Occurrence of Leishmania (Leishmania) chagasi in a domestic cat (Felis catus) in Andradina, São Paulo, Brazil: case report. Rev Bras Parasitol Vet 2010; 19(4): 256-258. http://dx.doi. org/10.1590/S1984-29612010000400013. PMid:21184705.

Coelho WMD, Richini-Pereira VB, Langoni H, Bresciani KDS. Molecular detection of Leishmania sp. in cats (Felis catus) from Andradina Municipality, São Paulo State, Brazil. Vet Parasitol 2011; 176(2-3): 281-282. http://dx.doi.org/10.1016/j.vetpar.2010.10.052. PMid:21130575.

Cortes S, Maurício IL, Kuhls K, Nunes M, Lopes C, Marcos M, et al. Genetic diversity evaluation on Portuguese Leishmania infantum strains by multilocus microsatellite typing. Infect Genet Evol 2014; 26: 20-31. http://dx.doi.org/10.1016/j.meegid.2014.04.023. PMid:24815728.

Costa TAC, Rossi CN, Laurenti MD, Gomes AAD, Vides JP, Vicente Sobrinho LS, et al. Ocorrência de leishmaniose em gatos de área endêmica para leishmaniose visceral. Braz J Vet Res Anim Sci 2010; 47(3): 213-217. http://dx.doi.org/10.11606/issn.16784456.bjvras.2010.26858.

Coura FM, Passos SKP, Pelegrino MOF, Leme FOP, Paz GF, Gontijo CMF, et al. Serological, molecular, and microscopic detection of Leishmania in cats (Felis catus) in Belo Horizonte, Minas Gerais State, Brazil. Rev Bras Parasitol Vet 2018; 27(4): 570-574. http:// dx.doi.org/10.1590/s1984-296120180052. PMid:30183999.

Cupolillo E, Momen H, Grimaldi G Jr. Genetic diversity in natural populations of New World Leishmania. Mem Inst Oswaldo Cruz 1998; 93(5): 663-668. http://dx.doi.org/10.1590/S0074-02761998000500018. PMid:9830535.

Darriba D, Taboada GL, Doallo R, Posada D. jModelTest 2: more models, new heuristics and parallel computing. Nat methods 2012; 9(8): 772-772. https://doi.org/10.1038 /nmeth.2109. 
Degrave W, Fernandes O, Campbell D, Bozza M, Lopes U. Use of molecular probes and PCR for detection and typing of Leishmania - a mini-review. Mem Inst Oswaldo Cruz 1994; 89(3): 463-469. http://dx.doi.org/10.1590/S0074-02761994000300032. PMid:7476234.

Diakou A, Papadopoulos E, Lazarides K. Specific anti-Leishmania spp. antibodies in stray cats in Greece. J Feline Med Surg 2009; 11(8): 728-730. http://dx.doi.org/10.1016/j.jfms.2008.01.009. PMid:19254858.

El Tai NO, Osman OF, El Fari M, Presber W, Schönian G. Genetic heterogeneity of ribosomal internal transcribed spacer in clinical samples of Leishmania donovani spotted on filter paper as revealed by single-strand conformation polymorphisms and sequencing. Trans R Soc Trop Med Hyg 2000; 94(5): 575-579. http://dx.doi.org/10.1016/S0035-9203(00)90093-2. PMid:11132393.

Guindon S, Dufayard JF, Lefort V, Anisimova M, Hordijk W, Gascuel O. New algorithms and methods to estimate maximumlikelihood phylogenies: assessing the performance of PhyML 3.0. Syst Bio/ 2010; 59(3): 307-321. http://dx.doi.org/10.1093/sysbio/ syq010. PMid:20525638.

Loeuillet C, Bañuls AL, Hide M. Study of Leishmania pathogenesis in mice: experimental considerations. Parasit Vectors 2016; 9(1): 144. http://dx.doi.org/10.1186/s13071-016-1413-9. PMid:26969511.

Lopes AP, Oliveira AC, Granada S, Rodrigues FT, Papadopoulos E, Schallig H, et al. Antibodies to Toxoplasma gondii and Leishmania spp. in domestic cats from Luanda, Angola. Vet Parasitol 2017; 239: 15-18. http://dx.doi.org/10.1016/j.vetpar.2017.04.009. PMid:28495190.

Luciano RM, Lucheis SB, Troncarelli MZ, Luciano DM, Langoni H. Avaliação da reatividade cruzada entre antígenos de Leishmania spp e Trypanosoma cruzi na resposta sorológica de cães pela técnica de imunofluorescência indireta (RIFI). Braz J Vet Res Anim Sci 2009; 46(3): 181-187. http://dx.doi.org/10.11606/issn.1678-4456.bjvras.2009.26765.

Maia C, Campino L. Can domestic cats be considered reservoir hosts of zoonotic leishmaniasis? Trends Parasitol 2011; 27(8): 341-344. http://dx.doi.org/10.1016/j.pt.2011.03.008. PMid:21570915.

Maia C, Gomes J, Cristóvão J, Nunes M, Martins A, Rebêlo E, et al. Feline Leishmania infection in a canine leishmaniasis endemic region, Portugal. Vet Parasitol 2010; 174(3-4): 336-340. http://dx.doi.org/10.1016/j.vetpar.2010.08.030. PMid:20869810.

Marcili A, Sperança MA, da Costa AP, Madeira MD, Soares HS, Sanches C, et al. Phylogenetic relationships of Leishmania species based on trypanosomatid barcode (SSU rDNA) and gGAPDH genes: taxonomic revision of Leishmania (L.) infantum chagasi in South America. Infect Genet Evol 2014; 25: 44-51. http://dx.doi.org/10.1016/j.meegid.2014.04.001. PMid:24747606.

Maroli M, Pennisi MG, Di Muccio T, Khoury C, Gradoni L, Gramiccia M. Infection of sandflies by a cat naturally infected with Leishmania infantum. Vet Parasitol 2007; 145(3-4): 357-360. http://dx.doi.org/10.1016/j.vetpar.2006.11.009. PMid:17174035.

Martín-Sánchez J, Acedo C, Muñoz-Pérez M, Pesson B, Marchal O, Morillas-Márquez F. Infection by Leishmania infantum in cats: epidemiological study in Spain. Vet Parasitol 2007; 145(3-4): 267-273. http://dx.doi.org/10.1016/j.vetpar.2006.11.005. PMid:17157440.

Minh BQ, Nguyen MAT, von Haeseler A. Ultrafast approximation for phylogenetic bootstrap. Mol Biol Evol 2013; 30(5): 1188-1195. http://dx.doi.org/10.1093/molbev/mst024. PMid:23418397.

Mohammadiha A, Mohebali M, Haghighi A, Mahdian R, Abadi AR, Zarei Z, et al. Comparison of real-time PCR and conventional PCR with two DNA targets for detection of Leishmania (Leishmania) infantum infection in human and dog blood samples. Exp Parasitol 2013; 133(1): 89-94. http://dx.doi.org/10.1016/j.exppara.2012.10.017. PMid:23159412.

Mohebali M, Malmasi A, Khodabakhsh M, Zarei Z, Akhoundi B, Hajjaran H, et al. Feline leishmaniosis due to Leishmania infantum in Northwest Iran: the role of cats in endemic areas of visceral leishmaniosis. Vet Parasitol Reg Stud Rep 2017; 9: 13-16. http:// dx.doi.org/10.1016/j.vprsr.2017.03.010. PMid:31014835.

Nasereddin A, Salant H, Abdeen Z. Feline leishmaniasis in Jerusalem: serological investigation. Vet Parasitol 2008; 158(4): 364-369. http://dx.doi.org/10.1016/j.vetpar.2008.09.022. PMid:18986768.

Nguyen LT, Schmidt HA, Von Haeseler A, Minh BQ. IQ-TREE: a fast and effective stochastic algorithm for estimating maximumlikelihood phylogenies. Mol Biol Evol 2015; 32(1): 268-274. http://dx.doi.org/10.1093/molbev/msu300. PMid:25371430.

Noe P, Domingos SL, Oshiro ET, Lima RB, Pirmez C, Pedroso TC, et al. Detection of Leishmania chagasi in cats (Felis catus) from viscera leishmaniasis endemic area in Brazil. Ciênc Anim 2015; 25(4): 3-14.

Oliveira GC, Paiz LM, Menozzi BD, Lima MS, Moraes CCG, Langoni H. Antibodies to Leishmania spp. in domestic felines. Rev Bras Parasitol Vet 2015a; 24(4): 464-470. http://dx.doi.org/10.1590/S1984-29612015071. PMid:26689182.

Oliveira TMFS, Pereira VF, Benvenga GU, Martin MFA, Benassi JC, Silva DT, et al. Conjunctival swab PCR to detect Leishmania spp. in cats. Rev Bras Parasitol Vet 2015b; 24(2): 220-222. http://dx.doi.org/10.1590/S1984-29612015016. PMid:26154963.</jrn>b

Ortuño M, Latrofa MS, Iborra MA, Pérez-Cutillas P, Bernal LJ, Risueño J, et al. Genetic diversity and phylogenetic relationships between Leishmania infantum from dogs, humans and wildlife in south-east Spain. Zoonoses Public Health 2019; 66(8): 961-973. http://dx.doi.org/10.1111/zph.12646. PMid:31512370. 
Otranto D, Napoli E, Latrofa MS, Annoscia G, Tarallo VD, Greco G, et al. Feline and canine leishmaniosis and other vector-borne diseases in the Aeolian Islands: pathogen and vector circulation in a confined environment. Vet Parasitol 2017; 236 : $144-151$. http://dx.doi.org/10.1016/j.vetpar.2017.01.019. PMid:28288759.

Pace D. Leishmaniasis. J Infect 2014; 69(Suppl 1): S10-S18. http://dx.doi.org/10.1016/j.jinf.2014.07.016. PMid:25238669.

Passos VM, Lasmar EB, Gontijo CM, Fernandes O, Degrave W. Natural infection of a domestic cat (Felis domesticus) with Leishmania (Viannia) in the metropolitan region of Belo Horizonte, state of Minas Gerais, Brazil. Mem Inst Oswaldo Cruz 1996; 91(1): 19-20. http://dx.doi.org/10.1590/S0074-02761996000100003. PMid:8734945.

Pennisi MG, Cardoso L, Baneth G, Bourdeau P, Koutinas A, Miró G, et al. LeishVet update and recommendations on feline leishmaniosis. Parasit Vectors 2015; 8(1): 302. http://dx.doi.org/10.1186/s13071-015-0909-z. PMid:26041555.

Pennisi MG, Persichetti MF. Feline leishmaniosis: is the cat a small dog? Vet Parasito/2018; 251: 131-137. http://dx.doi.org/10.1016/j. vetpar.2018.01.012. PMid:29426470.

Pennisi MG. Leishmaniosis of companion animals in Europe: an update. Vet Parasitol 2015; 208(1-2): 35-47. http://dx.doi. org/10.1016/j.vetpar.2014.12.023. PMid:25573248.

Pereira A, Parreira R, Cristóvão JM, Castelli G, Bruno F, Vitale F, et al. Phylogenetic insights on Leishmania detected in cats as revealed by nucleotide sequence analysis of multiple genetic markers. Infect Genet Evol 2020; 77: 104069. http://dx.doi.org/10.1016/j. meegid.2019.104069. PMid:31670155.

Persichetti MF, Pennisi MG, Vullo A, Masucci M, Migliazzo A, Solano-Gallego L. Clinical evaluation of outdoor cats exposed to ectoparasites and associated risk for vector-borne infections in southern Italy. Parasit Vectors 2018; 11(1): 136. http://dx.doi. org/10.1186/s13071-018-2725-8. PMid:29554931.

Pimenta P, Alves-Pimenta S, Barros J, Barbosa P, Rodrigues A, Pereira MJ, et al. Feline leishmaniosis in Portugal: 3 cases (year 2014). Vet Parasitol Reg Stud Rep 2016; 1-2: 65-69. http://dx.doi.org/10.1016/j.vprsr.2016.02.003. PMid:31018412.

Sanchez-Villeda H, Schroeder S, Flint-Garcia S, Guill KE, Yamasaki M, McMullen MD. DNAAlignEditor: DNA alignment editor tool. BMC Bioinformatics 2008; 9(1): 154. http://dx.doi.org/10.1186/1471-2105-9-154. PMid:18366684.

Savani ESMM, Oliveira Camargo MC, Carvalho MR, Zampieri RA, Santos MG, D'Áuria SR, et al. The first record in the Americas of an autochthonous case of Leishmania (Leishmania) infantum chagasi in a domestic cat (Felix catus) from Cotia County, São Paulo State, Brazil. Vet Parasitol 2004; 120(3): 229-233. http://dx.doi.org/10.1016/j.vetpar.2004.01.008. PMid:15041097.

Schönian G, Nasereddin A, Dinse N, Schweynoch C, Schallig HDFH, Presber W, et al. PCR diagnosis and characterization of Leishmania in local and imported clinical samples. Diagn Microbiol Infect Dis 2003; 47(1): 349-358. http://dx.doi.org/10.1016/ S0732-8893(03)00093-2. PMid:12967749.

Schubach TMP, Figueiredo FB, Pereira SA, Madeira MF, Santos IB, Andrade MV, et al. American cutaneous leishmaniasis in two cats from Rio de Janeiro, Brazil: first report of natural infection with Leishmania (Viannia) braziliensis. Trans R Soc Trop Med Hyg 2004; 98(3): 165-167. http://dx.doi.org/10.1016/S0035-9203(03)00040-3. PMid:15024926.

Sherry K, Miró G, Trotta M, Miranda C, Montoya A, Espinosa C, et al. A serological and molecular study of Leishmania infantum infection in cats from the Island of Ibiza (Spain). Vector Borne Zoonotic Dis 2011; 11(3): 239-245. http://dx.doi.org/10.1089/ vbz.2009.0251. PMid:20804432.

Silva FOL. Ecoepidemiologia e Controle da Leishmaniose Visceral no município de Belo Horizonte (Minas Gerais, Brasil) [Tese]. Belo Horizonte: Fundação Oswaldo Cruz; 2015.

Silva RCN, Ramos RAN, Pimentel DS, Oliveira GMA, Carvalho GA, Santana MA, et al. Detection of antibodies against Leishmania infantum in cats (Felis catus) from the state of Pernambuco, Brazil. Rev Soc Bras Med Trop 2014; 47(1): 108-109. http://dx.doi. org/10.1590/0037-8682-0005-2012. PMid:24603746.

Silva SM, Rabelo PFB, Gontijo NF, Ribeiro RR, Melo MN, Ribeiro VM, et al. First report of infection of Lutzomyia longipalpis by Leishmania (Leishmania) infantum from a naturally infected cat of Brazil. Vet Parasitol 2010; 174(1-2): 150-154. http://dx.doi. org/10.1016/j.vetpar.2010.08.005. PMid:20832944.

Silveira L No, Marcondes M, Bilsland E, Matos LVS, Viol MA, Bresciani KDS. Clinical and epidemiological aspects of feline leishmaniasis in Brazil. Semina: Ciênc Agrár 2015; 36(3): 1467-1480. http://dx.doi.org/10.5433/1679-0359.2015v36n3p1467.

Simões-Mattos L, Mattos MRF, Teixeira MJ, Oliveira-Lima JW, Bevilaqua CML, Prata-Júnior RC, et al. The susceptibility of domestic cats (Felis catus) to experimental infection with Leishmania braziliensis. Vet Parasitol 2005; 127(3-4): 199-208. http://dx.doi. org/10.1016/j.vetpar.2004.10.008. PMid:15710520.

Soares CSA, Duarte SC, Sousa SR. What do we know about feline leishmaniosis? J Feline Med Surg 2016; 18(6): 435-442. http:// dx.doi.org/10.1177/1098612X15589358. PMid:26116620. 
Sobrinho LS, Rossi CN, Vides JP, Braga ET, Gomes AA, Lima VM, et al. Coinfection of Leishmania chagasi with Toxoplasma gondii, Feline Immunodeficiency Virus (FIV) and Feline Leukemia Virus (FeLV) in cats from an endemic area of zoonotic visceral leishmaniasis. Vet Parasitol 2012; 187(1-2): 302-306. http://dx.doi.org/10.1016/j.vetpar.2012.01.010. PMid:22285010.

Solano-Gallego L, Iniesta L, Rodríguez-Cortés A, Pastor J, Quintana J, Espada Y, et al. Cross-sectional serosurvey of feline leishmaniasis in ecoregions around the Northwestern Mediterranean. Am J Trop Med Hyg 2007; 76(4): 676-680. http://dx.doi. org/10.4269/ajtmh.2007.76.676. PMid:17426169.

Souza Al, Barros EMS, Ishikawa E, Ilha IMN, Marin GRB, Nunes VLB. Feline leishmaniasis due to Leishmania (Leishmania) amazonensis in Mato Grosso do Sul State, Brazil. Vet Parasitol 2005; 128(1-2): 41-45. http://dx.doi.org/10.1016/j.vetpar.2004.11.020. PMid:15725531.

Souza NA, Leite RS, Silva SO, Penna MG, Vilela LFF, Melo MN, et al. Detection of mixed Leishmania infections in dogs from an endemic area in southeastern Brazil. Acta Trop 2019; 193: 12-17. http://dx.doi.org/10.1016/j.actatropica.2019.02.016. PMid:30772331.

Spada E, Canzi I, Baggiani L, Perego R, Vitale F, Migliazzo A, et al. Prevalence of Leishmania infantum and co-infections in stray cats in northern Italy. Comp Immunol Microbiol Infect Dis 2016; 45: 53-58. http://dx.doi.org/10.1016/j.cimid.2016.03.001. PMid:27012922.

Spada E, Proverbio D, Migliazzo A, Della Pepa A, Perego R, De Giorgi GB. Serological and molecular evaluation of Leishmania infantum Infection in stray cats in a nonendemic area in Northern Italy. ISRN Parasitol 2013; 2013: 916376. http://dx.doi. org/10.5402/2013/916376. PMid:27335864.

Vides JP, Schwardt TF, Sobrinho LSV, Marinho M, Laurenti MD, Biondo AW, et al. Leishmania chagasi infection in cats with dermatologic lesions from an endemic area of visceral leishmaniosis in Brazil. Vet Parasitol 2011; 178(1-2): 22-28. http://dx.doi. org/10.1016/j.vetpar.2010.12.042. PMid:21282011.

Voller A, Bidwell DE, Bartlett A. The Enzyme Linked Immunosorbent Assay (ELISA): a guide with abstracts of microplate applications. Europe, Guernsey: Dynatech Bidwell; 1979. 
Leishmaniasis in cats

\section{Supplementary Material}

Supplementary material accompanies this paper.

Figure S1: Phylogenetic trees of Brazilian field sequences and foreign sequences.

This material is available as part of the online article from http://www.scielo.br/rbpv 